\title{
DESIGN AND DEVELOPMENT OF THE VIBRANT SOUNDBRIDGE - A 25-YEAR PERSPECTIVE
}

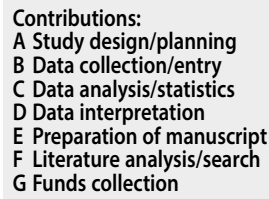

\section{Geoffrey Robert Ball ${ }^{B-C, E}$, Karin Rose-Eichberger ${ }^{A-C, E}$}

Business Unit Vibrant, Med-El Medical Electronics, Austria

Corresponding author: Karin Rose-Eichberger; Business Unit Vibrant, Med-El Medical Electronics, Fürstenweg 77a, A-6020, Innsbruck, Austria; email: karin.rose-eichberger@medel.com

\begin{abstract}
The Vibrant Soundbridge is a semi-implantable "direct drive" hearing system for the treatment of hearing loss. People who are unsuccessful users of acoustic hearing aids or who are dissatisfied with their hearing aids have been successfully fitted with the device. The Vibrant Soundbridge is comprised of an external audio processor and an internal vibrating ossicular prosthesis, which together convert environmental sound into a vibratory signal delivered to the inner ear. This unique middle ear implant system has, over the past 25 years, proven to be an effective solution for many types of hearing loss - mild to severe sensorineural hearing loss, as well as for conductive or mixed hearing loss. This review gives an overview of the design and development of the system, with a focus on its biomechanics, over the last 25 years.
\end{abstract}

Key words: biomechanics $\bullet$ hearing loss $\bullet$ Vibrant Soundbridge $\bullet$ active middle ear implant $\bullet$ direct drive

\section{KONSTRUKCJA I ROZWÓJ IMPLANTU VIBRANT SOUNDBRIDGE Z PERSPEKTYWY}

\section{LAT}

\section{Streszczenie}

Vibrant Soundbridge jest to wszczepialne urządzenie bezpośrednio stymulujące układ słuchowy w leczeniu niedosłuchu. Osoby, które nie odnoszą korzyści z akustycznych aparatów słuchowych lub nie są zadowolone ze swoich aparatów słuchowych były z powodzeniem zaopatrywane w to urządzenie. Vibrant Soundbridge składa się z zewnętrznego procesora dźwięków i wewnętrznej, wibrującej protezy kosteczki słuchowej, które przekształcają dźwięki otoczenia w drgania przekazywane do ucha wewnętrznego. Ten wyjątkowy system implantu ucha środkowego w ciągu ostatnich 25 lat dowiódł swojej skuteczności w leczeniu wielu typów niedosłuchów - odbiorczego stopnia od lekkiego do znacznego oraz niedosłuchu przewodzeniowego i mieszanego. W tej pracy przedstawiamy przegląd konstrukcji i rozwoju systemu w ciągu ostatnich 25 lat, skupiając się na jego własnościach biomechanicznych.

Słowa kluczowe: biomechanika $\bullet$ niedosłuch $\bullet$ Vibrant Soundbridge • aktywny implant ucha środkowego • stymulacja bezpośrednia

\section{Introduction}

Non-electric hearing aids have been around for hundreds of years. In contrast, electric (and electronic) hearing aids are of relatively recent origin. The first U.S. patent for an electric hearing aid was applied for in January 1892 by A. E. Miltimore [1]. His patent was issued for a "magneto telephone for personal wear", but it seems he never manufactured it. In 1899, F. H. Collins received a patent for the first real hearing aid. Collins' device consisted of an electronic microphone, crude signal-processing electronics, a battery, and a speaker placed in the ear canal. The system amplified incoming acoustic signals and drove the tympanic membrane with amplified acoustic sound [2]. Two hearing aid patents were also issued to M. R. Hutchinson that same year. According to Berger, in 1898 (or at the latest 1899) Hutchinson and J. H. Wilson established what is probably the first company specifically formed to manufacture hearing aids. Hearing aids have improved considerably since the time of Collins, but the basic concept of a hearing aid as a device that utilizes a microphone, signal processor, speaker, and battery has not changed in over 100 years. When G. R. Ball and B. Katz started the Vibrant Soundbridge project, their goal was to develop a device that could provide the first surgical alternative for the hearing-impaired person suffering from sensorineural hearing loss.

\section{Background}

\section{Overview}

In 2018, the World Health Organization published new estimates on the extent of disabling hearing loss (defined as, for adults, hearing loss greater than $40 \mathrm{~dB}$ in the better hearing ear, and for children $0-14$ years, hearing loss greater than $30 \mathrm{~dB}$ in the better hearing ear). According to WHO, 466 million people worldwide (over 6\% of the world's population) suffer from hearing loss (congenital or acquired). Some $93 \%$ of these are adults (56\% males, $44 \%$ females) and $7 \%$ are children (estimates are based on the prevalence of hearing loss - https://www.who.int/pbd/ deafness/estimates/en/).

There are different types of hearing loss, including conductive, sensorineural, and mixed. People with hearing loss can benefit from devices such as hearing aids, cochlear implants, middle ear implants, active bone conduction implants, or other assistive device. According to WHO, current hearing aid production in 2017 met just 10\% of global need. 
Hearing implants can be a solution when conventional hearing aids fail to give sufficient benefit. Implants are also an option for individuals who are dissatisfied with conventional hearing aids or for those who cannot use conventional hearing aids. Implants are surgically implanted electronic devices that deliver sensations of sound to the hearing impaired wearer, and each type is designed for different sorts of hearing loss. Since this article concerns itself with the design and development of the Vibrant Soundbridge, we will only discuss this particular middle ear implant and the associated Vibroplasty Coupler.

The Soundbridge utilizes what is called 'direct drive' technology, offering a clearer, more natural sound quality without occluding the ear canal. A feature unique to the Soundbridge is a single point of attachment for its floating mass transducer (FMT). The FMT is the world's smallest highfidelity vibratory micro-actuator, weighing just $25 \mathrm{mg}$, and is the heart of the Soundbridge hearing implant. The following sections provide more details about direct drive, the Floating Mass Transducer, and the Vibrant Soundbridge.

\section{Direct drive}

Direct drive implantable middle ear hearing devices are unique. The potential advantages of this type of middle ear implant have been reported for a number of years by many investigators [3-5]. The concept of "direct drive" is simple: rather than use acoustic energy to vibrate the tympanic membrane and stimulate the middle ear, the idea is to vibrate the ossicular chain directly with mechanical vibrations. This provides the opportunity to deliver a high-quality signal to the inner ear (the target structure) by avoiding acoustic effects (e.g. occlusion) in the ear canal $[6,7]$. The successful implementation of this type of direct drive device solves many of the issues inherent with conventional acoustic devices by reducing occlusion and feedback while providing significant levels of amplified signal over a wider frequency spectrum.

Numerous attempts have been made to realize the development of a direct drive device that could be physically accommodated by the middle ear [8-14]. Previous designs have generally had significant issues with delivering adequate mechanical energy or consuming too much power for practical daily use. As a result, devices were limited to treatment of conductive hearing loss. However, reports from patients of a "better and clearer" sound quality were consistently observed in laboratory experiments and inspired continued development efforts.

Historically, direct drive development efforts have focused on the design of the mechanical transducer. Many transducer designs required complex surgical procedures, and some require disarticulation or interruption of the ossicular chain [15-17]. Such approaches interfere with an implanted subject's residual hearing and can leave the patient in a worse condition should the implanted device prove ineffective in improving hearing. Moreover, many designs that have both the input output stages attached to the mastoid can lead to feedback via bone conduction.

G. R. Ball and B. Katz sought to invent a system that utilized a new class of transducer that works in concert with the normal biomedical function of the middle ear to enhance its vibratory motion. Their design utilizes a concept called "inertial drive." A primary advantage of inertial drive transducers over other designs is that they offer a way to drive the ossicular chain without requiring additional support armatures. In theory, an inertial drive device can be designed so that it overcomes most of the drawbacks of previous approaches. One device that utilizes the inertial drive concept is the Floating Mass Transducer, a key component of the Vibrant Soundbridge [18].

\section{Floating Mass Transducer (FMT)}

The two most common vibratory transducer types are electromagnetic and piezoelectric, with the latter usually larger than the former. Due to their larger size, piezoelectric transducers normally require multiple points of attachment to be useful in the middle ear. In principle, a piezoelectric transducer with a single point of attachment are possible $[17,19]$, but currently there is no such system on the market. The majority of devices using electromagnetic transducers, specifically the FMT, are small.

The electromagnetic FMT (Figure 1) was conceived as a transducer that could produce vibrations of the cochlear fluid and stimulate hearing with minimal distortion. The framework for the design was based on guidelines for middle ear development published by Goode [5]. In addition to Goode's design guidelines, the following additional design constraints for the transducer were also utilized:

1. It and its mounting structure(s) should weigh no more than $50 \mathrm{mg}$ [20].

2. It should be no larger than $2 \mathrm{~mm}$ long and $1.5 \mathrm{~mm}$ in diameter.

3. It should be "tuned" to resonate at about $1500 \mathrm{~Hz}$.

4. It should mimic the vibratory response of the native ossicular chain.

5. It should have the ability to drive the ossicular chain at output levels required for the treatment of moderately severe to severe hearing loss without introducing unwanted distortion.

6. It should be attached to the ossicular chain in a way that would obviate the need for a supporting armature and not affect residual hearing.

The FMT of the Vibrant Soundbridge has been specifically designed to avoid mass-loading of the ossicular chain [12].

\section{Vibrant Soundbridge - the device}

The Vibrant Soundbridge (VSB) is a semi-implantable active middle ear implant system designed to provide therapy for sensorineural and conductive deafness in patients who, for medical reasons, cannot use or benefit from conventional acoustic hearing aids, or are dissatisfied with them. The VSB is a partially implantable direct drive middle ear implant that amplifies the mechanical vibrations of the middle ear ossicular chain, thereby delivering an amplified signal to the cochlea. Utilizing mechanical energy instead of acoustic energy (sound) presents the opportunity to deliver a more accurate signal to the inner ear. Direct drive devices can provide this signal without feedback or occlusion of the external ear canal, and in this way offer the user a substantial benefit that can enhance their quality of life. 


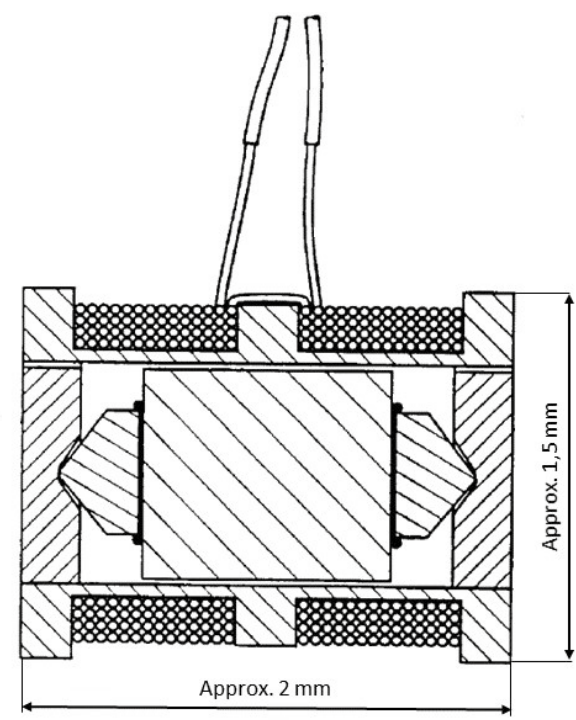

Figure 1. Cross-section of the FMT

For many years investigators have sought to develop an alternative treatment option for sensorineural hearing loss. The VSB is comprised of external and internal units. The external component is the audio processor (AP) and the implanted unit is called the Vibrating Ossicular Prosthesis (VORP). It is the only middle ear implant that attaches to just one vibratory structure of the middle ear. Those who are unsuccessful in using acoustic hearing aids, or are dissatisfied with them, have been successfully fitted with the Soundbridge [21].

Patient satisfaction and performance of the Soundbridge have been high and consistent across centres, countries, and continents [22-27]. In general, patients who wear the device all day (up to $16 \mathrm{~h}$ ), report a natural sound quality, high device satisfaction, and a better ability to understand speech, especially in noisy environments [21].

\section{Previous attempts at deafness treatment with vi- bratory implants}

The development of direct-drive middle ear implants has had a long history. The first serious and well-funded research attempts were done by Suzuki and Yanigihara [28]. In the early 1980's, two types of middle ear implantable hearing aids (totally implantable, T-MEI; and partially implantable, $\mathrm{P}-\mathrm{MEI}$ ) were developed in collaboration with the Rion hearing aid company in Japan. Though the early results were successful, the piezoelectric device (P-MEI) was clinically investigated in about 100 subjects, but it was never brought to market. Other development efforts in the field include Richards Medical (now Smith and Nephew) that worked on Jorgen Heide's middle ear electromagnetic total ossicular replacement prosthesis (TORP) device, the efforts of Perkins and Goode with the ReSound Earlens (now EarLens Corporation; a new version of the Earlens was approved in 2015 by FDA), the TICA (totally implantable communication assistance: a vibratory amplifier implant) developed by Leysieffer and Zenner and now owned by Cochlear Corporation [29], and the work of many others, including Maniglia, Hough, Spindel, and Hüttenbrink.

\section{Middle ear biomechanics}

The human ear is a complex biomechanical system having three parts: outer, middle, and inner ear. The middle ear contains three ossicles (malleus, incus, and stapes) which transmit the vibrations of the tympanic membrane (ear drum) to the cochlea. Understanding the biomechanics of the human middle ear has been helped by the development of non-contact laser Doppler vibrometers to measure the sub-microscopic vibration patterns of the middle ear, either in vitro or in vivo. Motions of the middle

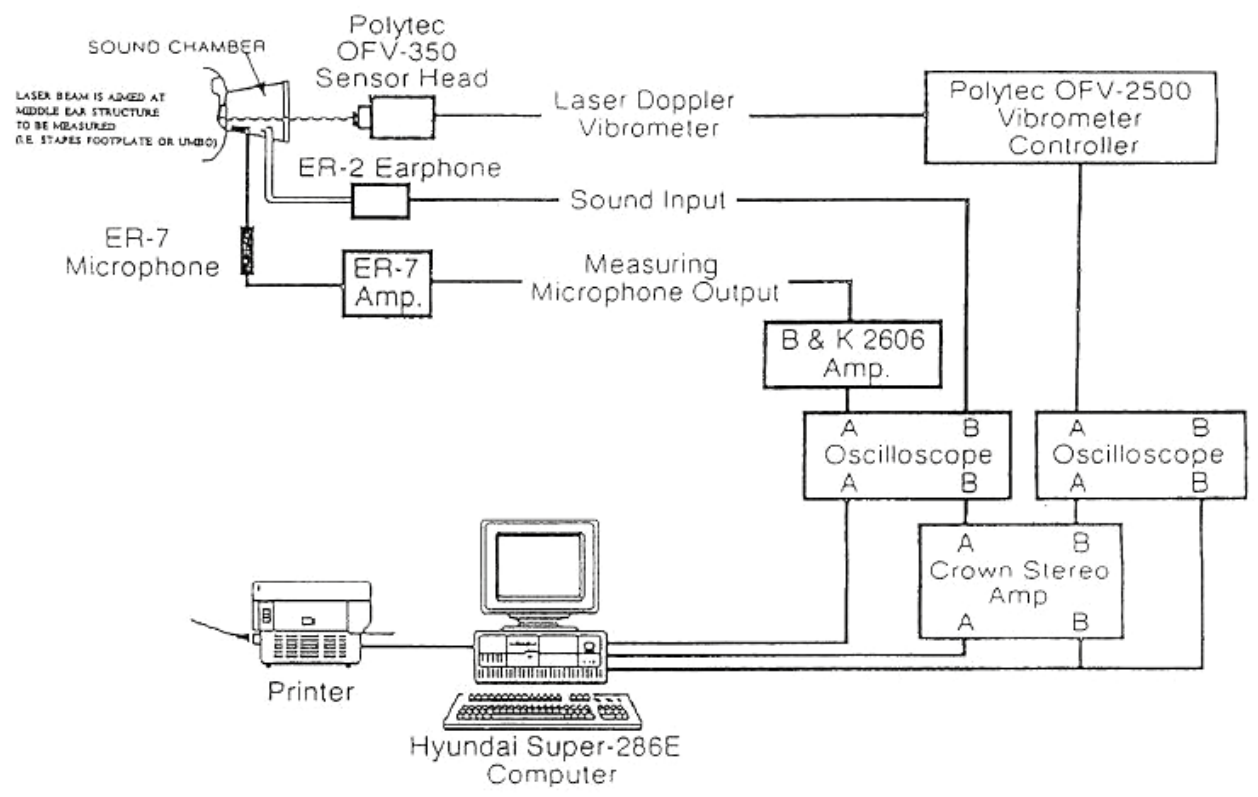

Figure 2. The central role of the laser Doppler velocimeter (LDV) system. The system was developed by G. R. Ball at the laboratory of Dr Richard Goode. The software used to record measurements was developed by Dr Jont Allen 
ear are typically less than $100 \mathrm{~nm}$ under physiological conditions, so driving the ossicles requires only a minute force, and the slightest vibration will be interpreted by the brain as a very loud sound (at the stapes footplate $1 \mu \mathrm{m}=120 \mathrm{~dB}$ at $1 \mathrm{kHz}$ ) [30]. These facts imply that very small transducers should be able to provide amplified sound to damaged or deafened ears. The operational theory behind the implantable system was mathematically modelled and based on biomechanical studies of the vibratory characteristics of the ossicular chain in normal human ears. A key to the discovery of the FMT was the development of a laser Doppler velocimeter (LDV) measurement system (Figure 2). Transducers were then analysed in the laboratory for functional and sound quality characteristics prior to clinical studies.

The transducer of the Vibrant Soundbridge system has been designed to provide adequate stimulation of the ossicles to provide the implanted patient with useful amplification over the key audio signal range, so that the user can experience the entire world of sound. Patients implanted with direct drive implants typically experience expanded appreciation of speech, and speech perception in noise in particular and also report high levels of music perception. The ability to deliver targeted hi-fidelity vibratory energy in direct proximity to the inner ear is an ideal advantage for direct drive hearing implants [31,32].

\section{Concept development}

Many transducers have been tried over the years. The Floating Mass Transducer (FMT) combines the strengths of a single point of attachment and an inertial drive transducer. The principal advantages of this design are that it can be made small and manufactured with only a limited number of parts. The single point of attachment makes placement of the FMT independent of skull growth and, due to its small size, it can be physically accommodated in nearly all human middle ears. This is an important issue for implantation in children and for patients with congenital malformations of the middle ear. The electromagnetic transducer can be hermetically sealed within a titanium housing and is thus biocompatible. It works in concert with the anatomy of the middle ear and has excellent frequency response, very high output levels, yet exceedingly low distortion. The FMT is the smallest high-fidelity device yet produced.

\section{Technology transfer and first patents}

Technology transfer of the Floating Mass Transducer device designs from Veterans Health Administration (VA) to Geoffrey Ball was begun in 1992. The first patent was filed in 1993 and issued in 1995. The Vibrant Soundbridge was developed in 1996 by Symphonix Devices Inc, and was first implanted in 1996 at the Universitätsspital Zürich.

\section{Funding}

Funding for the project came from the venture capital community. This was necessary because although the FMT was a relatively simple design to make, the first devices suitable for clinical studies in living humans would cost millions of dollars. This is due to the testing, regulatory, and good manufacturing practice requirements for active implantable Class III medical devices. Therefore, funding at a university or government research grant level was not feasible as these programs do not offer enough funding to cover initial costs. In fact, research grants would not even cover the initial costs for the custom equipment development that was required to manufacture the first medical grade FMTs.

In addition, development of the Vibrant Soundbridge required a team of engineers and a team of clinical experts to develop, manage, and execute the initial clinical trials, both in Europe and the U.S. At that time (in the early 1990s), government and university funding for large-scale clinical trials was rare and effectively nonexistent. Running clinical trials in large patient cohorts and in compliance with regulatory and clinical oversight agencies, costs millions of dollars. Large amounts of repeatable data are needed to meet the approval requirements of the U.S. FDA and of EU regulatory authorities.

\section{Project initiation}

After inventing the FMT, Geoffrey Ball sought the appropriate financial and technical resources to establish Symphonix Devices in 1994 so that his invention could be developed into a safe and effective device for treating hearing loss. For the next 3 years the company took its core technology, the Floating Mass Transducer, and developed the Vibrant Soundbridge [33]. The company's objective was to establish a family of Soundbridges (Table 1) - all utilizing the FMT technology - and make them the worldwide standard of care for the management of moderate to severe hearing loss.

Regarding the internal part (the Vibrating Ossicular Prosthesis or VORP), there have been two different versions, the VORP 501 and the VORP 502 (Table 2). The VORP 501 version was only used by Symphonix, whereas the VORP 502 version was used by Symphonix as well as Med-El.

\section{First implants in Europe and clinical trials}

In September 1996, Symphonix began clinical trials of the Vibrant Soundbridge in both the United States and Europe. The first patient in Europe was implanted with the Soundbridge in September 1996 [34]. In July 1997 Symphonix initiated clinical trials of the Vibrant P Soundbridge (= Symphonix second generation product) in Europe. In total, 47 patients were implanted with the Soundbridge: 19 subjects were fitted with the device consisting of the vibrating ossicular prosthesis (VORP) 501 and audio processor (AP) 301 (all upgraded to AP 302) and 28 subjects with the device consisting of the VORP 502 and AP 302 (Figure 3). The areas analysed included residual hearing, functional gain, AP settings, speech perception, volume, and device usage.

The results obtained were very positive for functional gain and performance. All major objective measures showed significant improvement. Data were similar to those found in the original clinical trial. There were many different studies that showed good consistent results even though they used different VORP and AP versions [35,36]. The technology 
Table 1. Vibrant Soundbridge versions under development by Symphonix Devices Inc

\begin{tabular}{|c|c|c|c|}
\hline Vibrant Soundbridge versions & Description & $\begin{array}{l}\text { Hearing loss } \\
\text { addressed }\end{array}$ & Comments \\
\hline $\begin{array}{l}\text { Vibrant } \\
\text { (VORP } 501 \text { \& AP 301) }\end{array}$ & $\begin{array}{l}\text { First generation semi-implantable hearing } \\
\text { device (HD) }\end{array}$ & $\begin{array}{l}\text { moderate to } \\
\text { moderately severe }\end{array}$ & $\begin{array}{l}\text { used for original clinical } \\
\text { trials in EU \& US }\end{array}$ \\
\hline $\begin{array}{l}\text { Vibrant P } \\
\text { (VORP } 501 \text { \& AP 302) }\end{array}$ & $\begin{array}{l}\text { Second generation semi-implantable HD, } \\
\text { programmable, analog, 2-channel, wide } \\
\text { dynamic range compression circuitry }\end{array}$ & $\begin{array}{l}\text { moderate to } \\
\text { severe }\end{array}$ & $\begin{array}{l}\text { used for clinical trials in } \\
\text { EU \& US }\end{array}$ \\
\hline $\begin{array}{l}\text { Vibrant HF } \\
\text { (VORP } 502 \text { \& AP 303) }\end{array}$ & $\begin{array}{l}\text { Second generation semi-implantable HD; } \\
\text { programmable, analog circuitry processing } \\
\text { only high frequency information }\end{array}$ & $\begin{array}{l}\text { moderate to } \\
\text { severe, noise- } \\
\text { induced high } \\
\text { frequency loss }\end{array}$ & $\begin{array}{l}\text { VORP } 502 \text { was released, } \\
\text { AP } 303 \text { was never released }\end{array}$ \\
\hline $\begin{array}{l}\text { Vibrant D } \\
\text { (VORP } 502 \text { \& AP 304) }\end{array}$ & $\begin{array}{l}\text { Third generation semi-implantable HD, fully } \\
\text { digital, 3-channel circuitry }\end{array}$ & $\begin{array}{l}\text { moderate to } \\
\text { severe }\end{array}$ & $\begin{array}{l}\text { RELEASED } \\
\text { first commercial product } \\
\text { sales EU \& US }\end{array}$ \\
\hline $\begin{array}{l}\text { Vibrant Soundbridge (VORP } 502 \text { \& } \\
\text { AP } 404 \text { SR) }\end{array}$ & $\begin{array}{l}\text { Model } 404 \text { AP with SR telemetry, new } \\
\text { housing, new digital signal processor, } \\
\text { supplied by Siemens Audiologische Technik }\end{array}$ & $\begin{array}{l}\text { moderate to } \\
\text { severe }\end{array}$ & RELEASED \\
\hline
\end{tabular}

Table 2. Vibrant Soundbridge VORPs under development by Symphonix Devices Inc.; continued by Med-El GmbH

\begin{tabular}{|c|c|c|c|}
\hline Soundbridge VORP & Description & Hearing loss addressed & Comments \\
\hline VORP 501 & Original first generation VORP & Only sensorineural & $\begin{array}{c}\text { Used for clinical trials in } \\
\text { EU \& US } \\
\text { (Symphonix } \\
\text { manufactured, } \\
\text { discontinued 1997) }\end{array}$ \\
\hline VORP 502 & $\begin{array}{c}\text { Second generation VORP and first commercially } \\
\text { available (optimised electronics) }\end{array}$ & $\begin{array}{c}\text { US: SNHL } \\
\text { EU: SNHL, MHL, and CHL }\end{array}$ & $\begin{array}{l}\text { Released } 1998 \text { in EU, } \\
2000 \text { in US } \\
\text { (Symphonix \& Med-El) }\end{array}$ \\
\hline VORP 503 & $\begin{array}{l}\text { Third generation VORP. Modifications to VORP } \\
\text { 502: MR-Conditional at } 1.5 \mathrm{~T} \text { now, conductor link } \\
\text { shortened by } 1 \mathrm{~cm} \text {, fixation wings (new feature). } \\
\text { Geometry optimisation: slightly thinner }\end{array}$ & $\mathrm{SNHL}, \mathrm{MHL}$, and $\mathrm{CHL}$ & $\begin{array}{l}\text { Released in } 2014 \text { by } \\
\text { Med-El }\end{array}$ \\
\hline
\end{tabular}

was steadily improved, and the device was approved with the CE Mark in February 1998.

\section{Clinical trials and U.S. FDA}

In February 1996 Symphonix received approval of an IDE (investigational device exemption) for the Vibrant Soundbridge from the FDA, and the first patient in the U.S. was implanted in October of that year. The pivotal phase of the clinical trial for the safety and effectiveness of the Vibrant Soundbridge began in 1998. In total, 99 patients were implanted in the US clinical trial which ended in August 2000. It was the largest number of implantable middle ear hearing device patients worldwide.

In summary, the Soundbridge provided equal or better functional gain compared to the patient's own hearing aid. Functional gain is calculated as the difference between preoperative unaided thresholds and post-operative VSB-aided thresholds obtained in free-field (at 3, 12, and 24 months post-activation). Because of the FMT's frequency response, and because it delivers the signal directly to the stapes, functional gain is equal or increased compared to the patient's own hearing aid, especially at high frequencies. The VSB does not significantly affect residual hearing, and $90 \%$ of US subjects showed $\leq 10 \mathrm{~dB}$ mean shift in residual

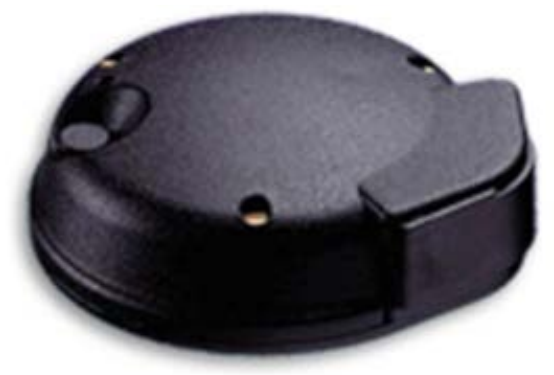

Figure 3. Audio processor AP 302 of the Vibrant Soundbridge

hearing and $96 \%$ of subjects had no shift in PTA $\geq 10 \mathrm{~dB}$. In terms of speech recognition, the Soundbridge was preferred over the hearing aid, based on a Symphonix-developed self-assessment tool. Testing of speech perception in a controlled sound field demonstrated equivalent group mean results between the Soundbridge and the patients' own hearing aids. As measured by the Profile of Hearing Aid Performance (PHAP) (hearing aid vs. VSB at 3 and 12 months), all seven subscales (familiar talkers, ease of communication, reduced cues, background noise, aversiveness of sounds, and distortion of sounds) were significantly improved ( $p<0.001$, Wilcoxon signed rank) with 


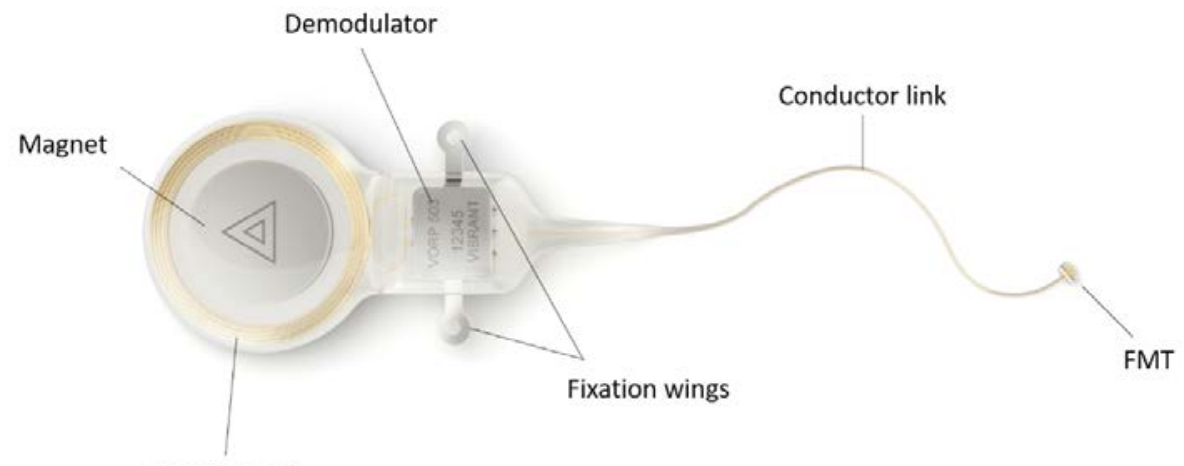

Receiver coil

Figure 4. Vibrant Soundbridge - the VORP 503

the Soundbridge. The safety of the device was addressed through stability of residual hearing and low incidence of adverse events. The most common comments from patients related to improved sound quality. Outcome measures showed that most patients reported significantly improved sound clarity, sound quality of their own voice, naturalness of sound, and overall sound quality. The VSB significantly reduced acoustic feedback compared to the patient's own hearing aid. Because the microphone and transducer are separate, the Soundbridge virtually eliminates acoustic feedback. During the clinical trial, only one of a patient's two ears was implanted, and so the safety and efficacy of the device relate only to monaural implantation. Patients were encouraged to continue binaural use by wearing their hearing aid in the other ear. The conclusions from the clinical trial offered significant reasons for a patient to consider the Soundbridge as an alternative to acoustic hearing aids. Several other studies have reported similar results.

\section{Safety issues}

Following the first device failures in the U.S. and in Europe, the company identified the failure mechanism and implemented a modification to the manufacturing process. The failure mechanism was a break in the gold wire of the conductor link due to strain from scar tissue. The manufacturing change involved reinforcement of the silicone elastomer and a pre-bend in the conductor link to place it below the level of scar tissue. Since the implementation of the change, there have been no further device failures.

\section{Product approval by U.S. FDA}

As the Vibrant Soundbridge is a Class III medical device, premarket approval by the FDA before commercialisation was required. The device was approved by the Food and Drug Administration in August 2000.

The 'Indications for Use' statement, as approved by the Food and Drug Administration, appears in the package insert and appropriately 'labels' or describes the potential patient that the device can help. After obtaining approval in 2000, the Soundbridge was indicated for use in adults, 18 years of age or older, who have a moderate to severe sensorineural hearing loss and desire an alternative to an acoustic hearing aid. Prior to receiving the device, it was recommended that individuals have experience with appropriately fitted hearing aids.

Above the standard audiological assessment, it was and still is important to provide appropriate counselling regarding the limitations and benefits of the Soundbridge compared to that of a hearing aid. For example, even though the Soundbridge provides better sound quality, individuals with poor word recognition will continue to struggle with their loss of cochlear function. Likewise, although the Soundbridge improves performance in background noise, individuals with hearing impairment, just like individuals with normal hearing, will encounter and need to cope with background noise. When considering hearing aid use, a major factor is monaural versus binaural use and what strategy the patient should use post-surgery - in other words, even with the Soundbridge, two ears are better than one in the majority of cases.

\section{The end of Symphonix and beginnings with Med-El}

Despite clinical success and approvals in both the U.S. and Europe, Symphonix Devices Inc. had the unfortunate experience of commencing its major United States market launch in Denver, Colorado at the annual AAO convention on September 11th, 2001. In November 2002, the company approved a plan of complete dissolution and liquidation. When Symphonix ended their business, the Austrian company Med-El, based in Innsbruck took over the Vibrant Soundbridge.

In June 2003 Med-El purchased the inventory, property and equipment, intellectual property, and assumed the product warranty of the Symphonix devices. In the same year Vibrant Med-El (since May 2016, Business Unit Vibrant) was founded. Since the start of its life with Med-El, the Soundbridge has been substantially improved and extended.

\section{Vibrant Soundbridge technology}

\section{VSB: State of the art hearing technology}

The focus of Med-El's technology is primarily on the magnetic field design of the electromechanical transducer (the Floating Mass Transducer for the Soundbridge and the 
Bonebridge). Through the use of highly miniaturised materials, the microtechnology of the FMT produces extremely small vibrations to stimulate the moving structures of the middle ear.

The Vibrant Soundbridge system consists of a VORP, Vibroplasty coupler, the audio processor, and accessories. The most recent model of the Soundbridge, the VORP 503 (Figure 4), is surgically implanted and consists of a receiver and MR-Conditional magnet, which is surrounded by an internal coil, a conductor link, electronics (demodulator), fixation wings, and the FMT. For cases of sensorineural hearing loss, the conductor link relays the signal from the receiver to the FMT, which is attached to the incus. In cases of mixed or conductive hearing loss, the FMT may be attached to the round window, to remnants of the stapes, or to the stapes footplate. The FMT converts the signal into vibrations that directly drive and move the vibratory structures of the middle ear and amplify their natural movement. These vibrations are conducted to the inner ear and lead to a normal stimulation of the hair cells within the cochlea.

The external part is called the audio processor (the latest model being the Samba 2; Figure 5), which is held against the head with a magnet and is powered by a standard hearing aid battery. The audio processor contains two microphones, which pick up sounds from the environment and convert them into a signal that is transmitted through the skin and received by the implanted internal receiver of the VSB.

The VSB's unique features include single point attachment to the skull. The processing unit, powered by a zinc-air battery, offers a wide range of individually adjustable programs. Life of the zinc-air batteries varies depending on the transmitter settings and user behaviour. On average, the battery needs to be replaced after about 5 days [37].

Originally, the FMT was applied to the round window in cases of conductive or mixed hearing loss. Now, various prostheses, known as Vibroplasty couplers (Figures 6 and 7 ), are available and offer new ways to attach the FMT to the ossicular chain and thus allow better adaptation to different anatomical conditions. The couplers were developed to enable the best way of coupling the FMT to remnants of the middle ear. The type is chosen on the basis of the state of the ossicular remnants and the presenting anatomy after surgical removal of all primary disease from the middle ear [38]. By using one of the Vibroplasty couplers, these passive middle ear prostheses provide surgeons with more flexibility in how to attach the FMT. The couplers were specially designed by collaboration between Med-El and surgeons.

Seven of the eight Vibroplasty couplers are made of titanium due to its biocompatibility, mechanical properties, and corrosion resistance. The exception is the new RW-Soft-Coupler, which is made of silicone instead.

\section{VORP - technical improvements}

In 2003 the Vibrant Soundbridge (VORP 502 with FMT attachment clip) was approved for sensorineural hearing loss. In 1998 the VSB gained approval in Europe for mild to severe hearing loss. In the United States, the device was approved in

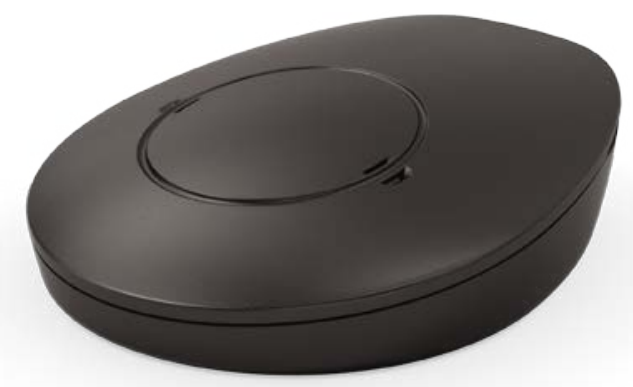

Figure 5. The Samba 2 audio processor of the Vibrant Soundbridge
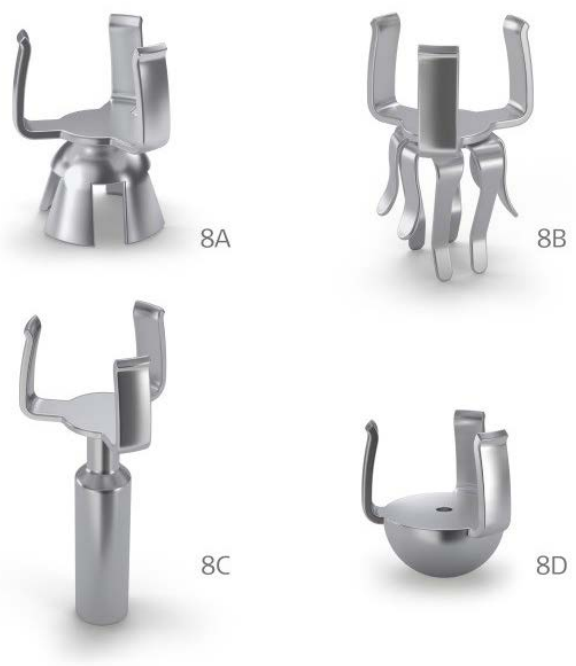

Figure 6. The original vibroplasty coupler prostheses. A: Vibroplasty-Bell-coupler (head of the stapes); B: Vibroplasty-CliP-coupler (head of the stapes); C: Vibroplasty-OW-coupler (oval window); and D: Vibroplasty-RW-coupler (round window)
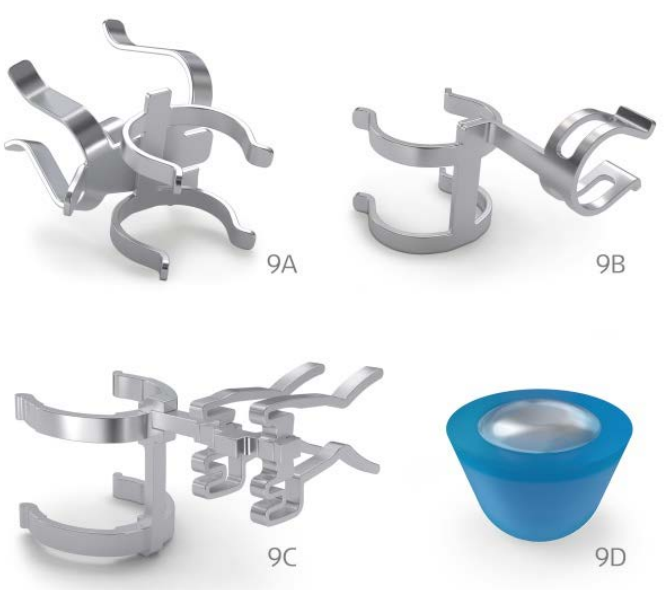

Figure 7. New vibroplasty couplers. A: Incus-SP-coupler, which attaches to the short process of the incus; $B$, IncusSymphonix-coupler, and C, Incus-LP-coupler, both which attach to the long process of the incus; and D: RW-Softcoupler, which attaches to the round window 
Table 3. Vibrant Soundbridge audio processors under development by Med-El GmbH

\begin{tabular}{|c|c|c|c|}
\hline Soundbridge audio processor & Description & $\begin{array}{l}\text { Hearing loss } \\
\text { addressed }\end{array}$ & Comments \\
\hline \multicolumn{4}{|l|}{ AP404 } \\
\hline & $\begin{array}{l}\text { First audio processor for the Vibrant Soundbridge. } \\
\text { Non-directional microphone. Analog signal processing }\end{array}$ & $\begin{array}{l}\text { moderate to } \\
\text { severe }\end{array}$ & $\begin{array}{c}\text { Transferred } \\
\text { to Med-El in } \\
2003\end{array}$ \\
\hline
\end{tabular}

Amadé
Major improvements are inclusion of directional
microphones. Redesigned plastic components for
improvement in appearance, size, and robustness. Digital moderate to
signal processing (16 bands, 8 compression channels).
Advanced pre-processing (noise-reduction, sound
smoothing, and wind-noise reduction
in 2009 by

Samba

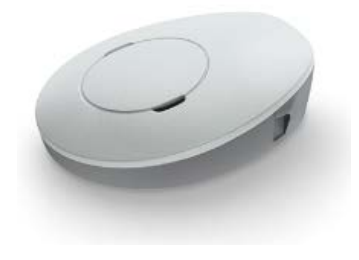

Basic functionality remains unchanged. Adaptive directional microphones. Digital signal processing (16 bands, 16 compression channels). Latest pre-processing (multi-channel noise reduction, sound smoothing, wind-noise reduction). Intelligent sound adapter (sound classifier, self-learning system). Wireless

moderate to Released in 2015 by severe Med-El connectivity (via miniTEK) and data logging

Samba 2

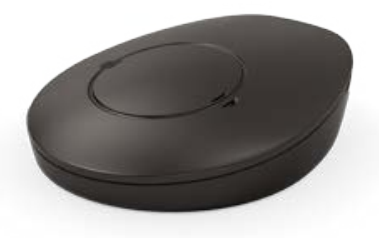

Basic functionality remains unchanged. Adaptive directional microphones. Digital signal processing (18 frequency bands, 18 compression channels). Latest pre-processing (multi-channel noise reduction, sound smoothing, wind-noise-reduction, directional speech

enhancement). Intelligent sound adapter (scene classifier with 6 environments (quiet, speech in quiet, noise, speech in noise, music, car), self-learning-system). Wireless connectivity (via SAMBA 2 GO) and data logging

$\begin{array}{cc}\begin{array}{c}\text { Released } \\ \text { severe }\end{array} & \begin{array}{c}\text { Releate } \\ \text { in 2020 by } \\ \text { Med-El }\end{array}\end{array}$

2000 for moderate to severe hearing loss. The first implantations of the Soundbridge with the transducer placed on the round window in patients with mixed and conductive hearing loss took place in 2005. In 2007 the Soundbridge obtained approval for conductive and mixed hearing loss in Europe. In 2009 the device was approved for use in children. In 2010, Med-El obtained approval for the Vibroplasty couplers for conductive and mixed hearing loss (VibroplastyOW-Coupler, Vibroplasty-CliP-Coupler, Vibroplasty-BellCoupler, and Vibroplasty-RW-Coupler). In November 2014, the new VORP 503 (with attachment clip-free and orientation-free FMT; successor to the VORP 502), was approved by TÜV Süd and launched. An overview of the differences between VORP 502 and 503 is shown in Table 2.

Since 2014, the Vibrant Soundbridge has been labelled MR Conditional: due to a special, patented magnet design of the VORP 503, the magnets inside the implant react neutrally to the magnetic field of an MRI scanner. The VORP
503 is currently the only CE-marked semi-implantable middle ear implant which is MR Conditional at 1.5 tesla. Also, in 2014, a new coupler generation for sensorineural hearing loss (Incus-SP-Coupler, Incus LP-Coupler) as well as conductive and mixed hearing loss (RW-Soft-Coupler) were launched. The aim was to optimise the system for all applications, but especially for SNHL. The primary focus is on the Incus-SP Coupler. It gives a new option for coupling to the short process of the incus without posterior tympanotomy (away from the facial nerve and chorda tympani). This new coupler has been developed to simplify surgical handling and offer surgical efficiency.

\section{Audio processor - technical improvements}

In 2009, a new audio processor for the Vibrant Soundbridge, Amadé, was introduced in Europe. Since 2012, vibrograms as an audiological tool can be created with the new Symfit software version for the Vibrant Soundbridge. In 2014, 
Table 4. Intended use Europe - SNHL: pure-tone air-conduction thresholds at or within the specified levels

\begin{tabular}{lcccccc}
\hline Frequency $(\mathbf{k H z})$ & $\mathbf{0 . 5}$ & $\mathbf{1}$ & $\mathbf{1 . 5}$ & $\mathbf{2}$ & $\mathbf{4}$ & 25 \\
\hline Lower limit $(\mathrm{dB} \mathrm{HL})$ & 10 & 10 & 10 & 15 & 80 \\
\hline Upper limit $(\mathrm{dB} \mathrm{HL})$ & 65 & 75 & 80 & 80 & 85 \\
\hline
\end{tabular}

Table 5. Intended use Europe - CHL and MHL: pure-tone bone-conduction thresholds at or within the specified levels

\begin{tabular}{lcccccc}
\hline Frequency $(\mathbf{k H z})$ & $\mathbf{0 . 5}$ & $\mathbf{1}$ & $\mathbf{1 . 5}$ & $\mathbf{2}$ & $\mathbf{3}$ & $\mathbf{4}$ \\
\hline $\mathrm{BC}$ upper limit $(\mathrm{dB} \mathrm{HL})$ & 45 & 50 & 55 & 65 & 65 & - \\
\hline
\end{tabular}

Table 6. Intended use U.S. - SNHL: pure-tone air-conduction thresholds at or within the specified levels

\begin{tabular}{lccccc}
\hline Frequency $(\mathbf{k H z})$ & $\mathbf{0 . 5}$ & $\mathbf{1}$ & $\mathbf{1 . 5}$ & $\mathbf{2}$ & $\mathbf{3}$ \\
\hline Lower limit $(\mathrm{dB} \mathrm{HL})$ & 30 & 40 & 45 & 45 & 50 \\
\hline Upper limit $(\mathrm{dB} \mathrm{HL})$ & 65 & 75 & 80 & 80 & 85 \\
\hline
\end{tabular}

the first market launch of the new VSB audio processor Samba took place. In April 2015 Samba was introduced by Vibrant Med-El as the successor to the Amadé audio processor. In July 2020 Samba 2 was introduced as the successor device to the Samba audio processor. An overview of the differences is shown in Table 3. In general, signal processing and functionality have improved over the generations.

\section{New indications for use}

Progressive maturation of technology and increased experience, along with good clinical results, have expanded the indications for Soundbridge implantation. In September 2007, the Soundbridge received approval to extend its indication criteria to mixed and conductive hearing losses in Europe, Canada, and many other countries. Short- and long-term results to date are favourable, letting users hear better in noisy environments and to communicate easily in day-to-day situations. Since then the Soundbridge has also been indicated for children with sensorineural, conductive, or mixed hearing loss (for countries with the CE mark, in Europe, and other countries worldwide). In 2009 the Soundbridge was approved for use in the paediatric market by EU authorities. Even today, this is the only middle ear implant system that features a single point attachment and therefore can be used for children.

\section{Europe - current status of intended use}

The Vibrant Soundbridge active middle ear implant is currently indicated for use in patients who have mildto-severe sensorineural (SNHL), conductive (CHL), or mixed (MHL) hearing loss. In addition, the field of Vibroplasty has been expanded by physicians employing the use of the Vibrant Soundbridge FMT technology in concert with reconstructive and restorative surgical techniques to treat hearing loss.

The current indications for eligible patients are as follows. A) Patients aged 5 years or older. B) An ear anatomy that can facilitate positioning of the FMT, so it is in contact with a suitable vibratory structure in the middle ear. C) Patients should be emotionally and psychologically stable with realistic expectations of the benefits of the Soundbridge. D) The pure-tone air-conduction thresholds should be at or within the levels listed in Table 4 (sensorineural hearing loss) or the pure-tone bone-conduction thresholds should be at or within the levels as listed in Table 5 (conductive and mixed hearing loss).

The contraindications are as follows: a patient who is known to be intolerant of the materials used in the implant (medical grade silicone elastomer, medical grade epoxy, and titanium), retrocochlear or central auditory disorders, nonresponsive active ear infection and/or chronic fluid in or about the ear, in cases where the hearing loss has demonstrated an improving or deteriorating fluctuation over a 2-year period of $15 \mathrm{~dB}$ in either direction, and a skin or scalp condition that may prelude attachment of the audio processor with a magnet. And finally: cases of physical, psychological, or emotional disorder that would interfere with surgery or the ability to perform test and rehabilitation procedures.

\section{United States - current status of intended use}

There are several pending efforts in the US to expand the indications for the Vibrant Soundbridge with FDA approval. At the moment the Soundbridge is used for adults (age 18 years or older) who suffer from moderate to severe sensorineural hearing loss and cannot use conventional hearing aids for medical reasons or do not benefit sufficiently from them. The current indications for eligible patients include, among others, pure-tone air-conduction thresholds at or within specified levels (Table 6) and a word recognition score of $50 \%$ or better using recorded material.

The contraindications are as follows: conductive hearing loss, retrocochlear or central auditory disorder, tympanic membrane perforations associated with recurrent middle ear infections, and a skin or scalp condition that may prelude attachment of the audio processor. 


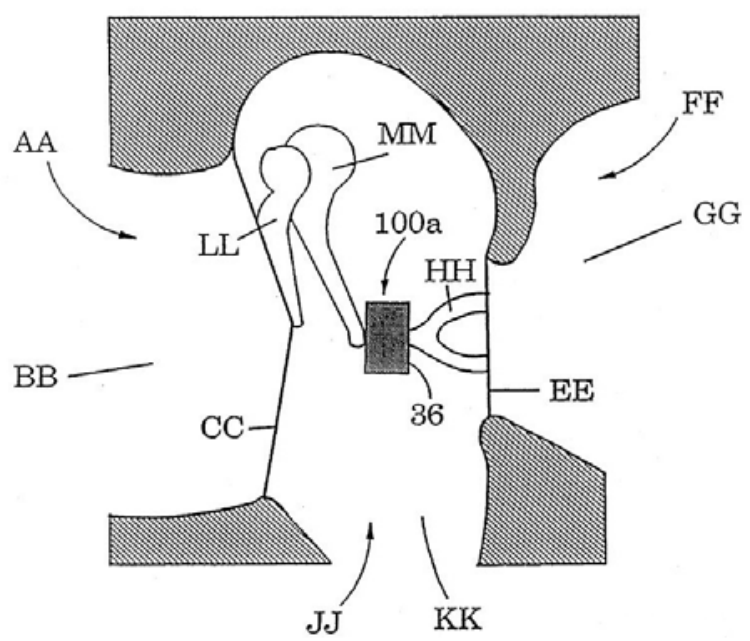

Figure 8. Original conception of an FMT interposed within the ossicular chain (G.R. Ball private collection, circa 1992)

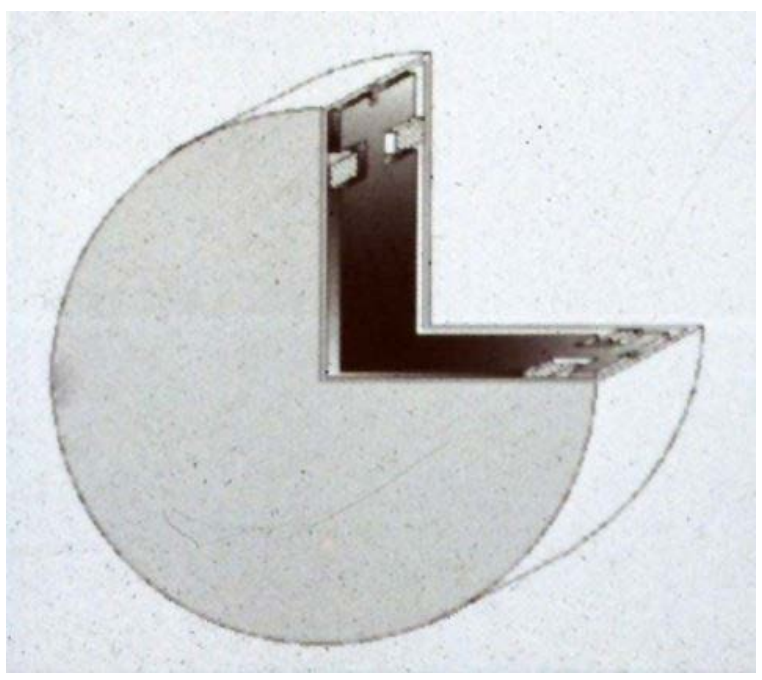

Figure 10. The first "cut away" view of an FMT (circa 1992 by G. R. Ball)

\section{Conclusion}

Since its conception, the Vibrant Soundbridge has, over the past 25 years, proven to be a safe and effective treatment for hearing loss or hearing disorders which previously had few or no treatment options. It has proven to be a flexible and reliable platform. Being the first active middle ear implant to be approved in the field, it has also uncovered the multi-faceted challenges facing technology development and successful implantation before widespread adoption can be achieved, including the raising of funds that exceed the amounts available to universities. Clearly, external funding is necessary to develop an implantable device, conduct expensive clinical studies, and obtain the extensive data required by regulators and authorities.

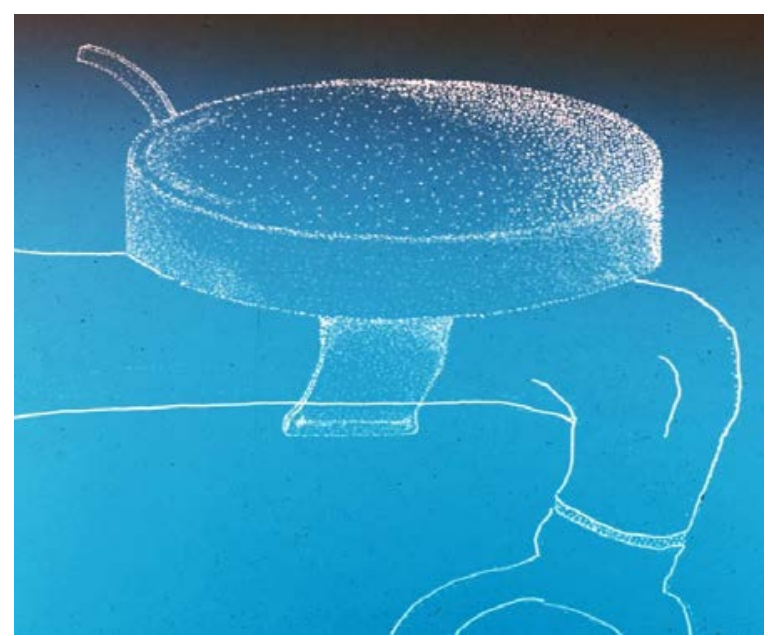

Figure 9. Original first drawing of an FMT for SNHL (collection of G. R. Ball, circa 1992)

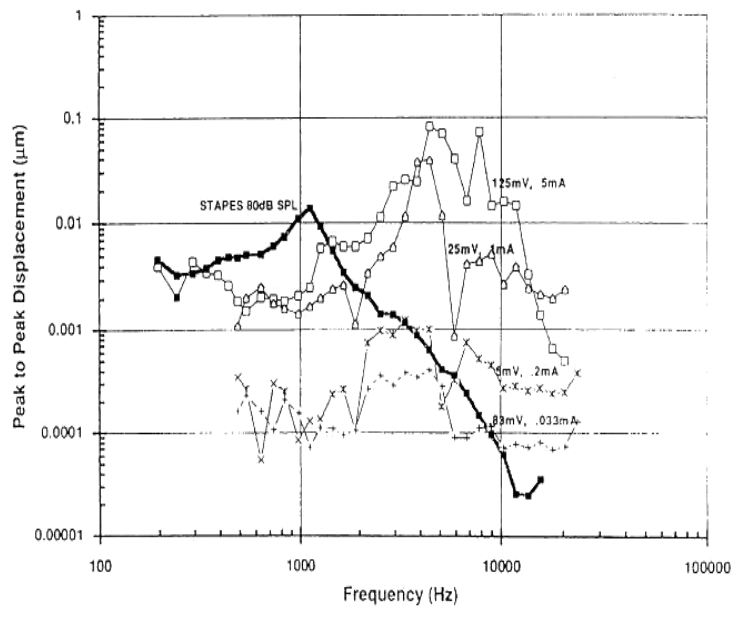

Figure 11. The frequency response of the first prototype transducer measured with an LDV in a temporal bone model (1993)

The VSB was developed 30 years ago and has been available in Europe since 1998, gaining FDA approval in 2000. It is the only active middle ear implant which has been on the market since 1998 while providing continuous upgrades to its users.

Today the Vibrant Soundbridge is used daily in more than 60 countries by physicians, hearing health care centres, and experts to treat hearing loss in ways that 25 years ago was impossible. New developments in the field of middle ear implants and Vibroplasty are continuing, and new devices and applications are now available from other suppliers. Reimbursement is an ever-challenging area for all new breakthroughs in medical technology. Further advances based on the latest research will no doubt 


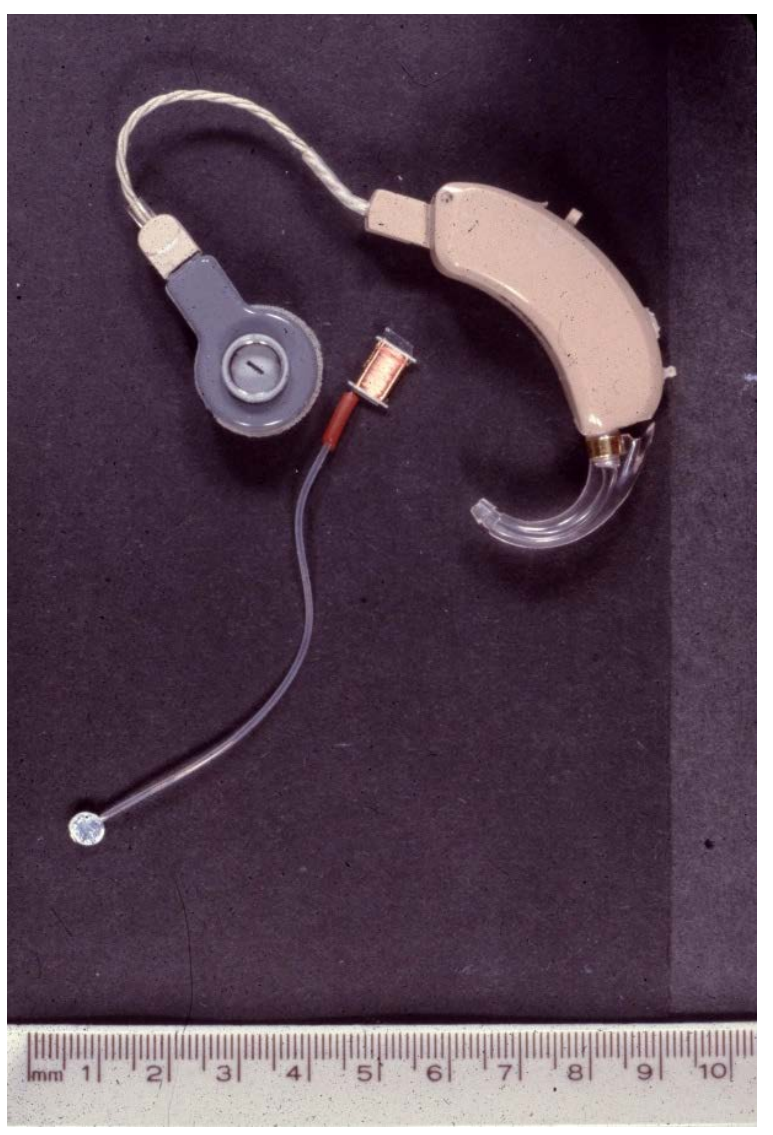

increase the potential application of vibratory hearing implants to treat hearing loss and offer expanded horizons for future research.

Managing the introduction of safe, effective, and new technologies into reimbursement markets in a responsible way within a reasonable time frame is key to making the latest innovations available to patients. We must always find ways to optimise patient access to the latest hearing technology and healthcare.

\section{Acknowledgements}

In 1996, Prof. Dr Ugo Fisch (Zürich, Switzerland) implanted the first Vibrant Soundbridge [34]. Since then, hundreds of engineers, physicians, hearing experts, regulators and business people have helped develop this industry and bring this new treatment area into existence. Research, innovation, and hard-working individuals and teams have brought about a renaissance in this area. The many determined physicians who use and implant the FMT technology have been instrumental in making great progress in this arena of treatment.
Figure 12. The first working system by G. R. Ball

\section{Appendix}

\section{A short journey through history: slides from 20 years ago}

In this section we would like to make a short journey through history via some of the inventor's first self-made slides to give an impression of the Vibrant Soundbridge's beginnings. Figure 8 shows the original conception of an FMT interposed on the ossicular chain (G. R. Ball private collection, circa 1992).

Figure 9 shows the original first drawing of an FMT for SNHL. The device is depicted here attached to the incus.

Figure 10 shows the first "cut away" view of an FMT (circa 1992 by G. R. Ball).

Figure 11 shows the frequency response of one of the first prototype transducers measured with an LDV in a temporal bone model (1993). The device was later improved with better output and response.

Figure 12 shows the first working system. G. R. Ball modified an old Xomed Audiant system and attached an early FMT (silver circle lower left) to a coil and proved the concept in its simplest form.

\section{References}

1. Miltimore AE. Magneto-telephone for personal wear. 1892. Available from https://patents.google.com/patent/US466725.
2. Berger KW. The hearing aid: its operation and development. 3rd Edition. Livonia, MI: National Hearing Aid Society; 1984. 
3. Wilska A. Eine Methode zur Bestimmung der Hörschwellenamplituden des Trommelfells bei verschiedenen Frequenzen. Skand Arch Für Physiol, 1935 Jul 1; 72: 161-5.

4. Glorig A, Moushegian G, Bringewald PR, Rupert AL, Gerken GM. Magnetically coupled stimulation of the ossicular chain: measures in kangaroo rat and man. J Acoust Soc Am, 1972 Aug 1; 52: 694-6.

5. Goode RL, Rosenbaum ML, Maniglia AJ. The history and development of the implantable hearing aid. Otolaryngol Clin North Am, 1995 Feb; 28: 1-16.

6. Békésy G v, Wever EG. Experiments in Hearing. New York: McGraw-Hill; 1960.

7. Peake WT. 'Experiments in Hearing' by Georg von Békésy [review]. J Acoust Soc Am, 1990 Dec 1; 88: 2905-6.

8. Heide J, Tatge G, Sander T, Gooch T, Prescott T. Development of a semi-implantable hearing device. Adv Audiol, 1988; 4: 32-43.

9. Maniglia AJ, Ko WH, Zhang RX, Dolgin SR, Rosenbaum ML, Montague FW. Electromagnetic implantable middle ear hearing device of the ossicular-stimulating type: principles, designs, and experiments. Ann Otol Rhinol Laryngol Suppl, 1988 Dec; 136: 3-16.

10. Hough J, Vernon J, Himelick T, Meikel M, Richard G, Dormer K. A middle ear implantable hearing device for controlled amplification of sound in the human: a preliminary report. Laryngoscope, 1987 Feb; 97: 141-51.

11. Maniglia AJ, Ko WH, Rosenbaum M, et al. A contactless electromagnetic implantable middle ear device for sensorineural hearing loss. Ear Nose Throat J, 1994 Feb; 73: 78-82, 84-8, 90.

12. Kartush JM, Tos M. Electromagnetic ossicular augmentation device. Otolaryngol Clin North Am, 1995 Feb; 28: 155-72.

13. Spindel JH, Lambert PR, Ruth RA. The round window electromagnetic implantable hearing aid approach. Otolaryngol Clin North Am, 1995 Feb; 28: 189-205.

14. Perkins R. Earlens tympanic contact transducer: a new method of sound transduction to the human ear. Otolaryngol Head Neck Surg, 1996 Jun; 114: 720-8.

15. Yanagihara N, et al: Efficacy of the partially implantable middle ear implant in the middle and inner ear disorders. Adv Audiol, 1988; 4: 149-59.

16. Zenner HP, Leysieffer H. [Active electronic hearing implants for middle and inner ear hearing loss - a new era in ear surgery. II: Current state of developments]. HNO, 1997 Oct; 45: 758-68.

17. Yanagihara N, Suzuki J, Gyo K, Syono H, Ikeda H. Development of an implantable hearing aid using a piezoelectric vibrator of bimorph design: state of the art. Otolaryngol Head Neck Surg, 1984 Dec; 92: 706-12.

18. Ball GR, Huber A, Goode RL. Scanning laser Doppler vibrometry of the middle ear ossicles. Ear Nose Throat J, 1997 Apr; 76: 213-8, 220, 222.

19. Hong E-P, Park I-Y, Seong K-W, Cho J-H. Evaluation of an implantable piezoelectric floating mass transducer for sensorineural hearing loss. Mechatronics, 2009 Sep; 19: 965-71.

20. Goode RL, Ball G, Nishihara S. Measurement of umbo vibration in human subjects: method and possible clinical applications. Am J Otol, 1993 May; 14(3): 247-51.

21. Haynes DS, Young JA, Wanna GB, Glasscock ME. Middle ear implantable hearing devices: an overview. Trends Amplif, 2009 Sep 1; 13: 206-14.
22. Fröhlich L, Plontke SK, Rahne T. A quantitative approach for the objective assessment of coupling efficiency for an active middle ear implant by recording auditory steady-state responses. Otol Neurotol, 2020 Aug; 41: e906-11.

23. Kließ MK, Ernst A, Wagner J, Mittmann P. The development of active middle ear implants: a historical perspective and clinical outcomes. Laryngoscope Investig Otolaryngol, 2018 Oct; 3: 394-404.

24. Burian A, Gerlinger I, Toth T, Piski Z, Rath G, Bako P. Stapedotomy with incus vibroplasty: a novel surgical solution of advanced otosclerosis and its place among existing therapeutic modalities - Hungarian single institutional experiences. Auris Nasus Larynx, 2020 Feb; 47: 55-64.

25. Hempel J-M, Sprinzl G, Riechelmann H, et al. A transcutaneous active middle ear implant (AMEI) in children and adolescents: long-term, multicenter results. Otol Neurotol, 2019; 40: 1059-67.

26. Zahnert T, Mlynski R, Löwenheim H, et al. Long-term outcomes of vibroplasty coupler implantations to treat mixed/conductive hearing loss. Audiol Neurootol, 2018; 23: 316-25.

27. Iwasaki S, Usami S-I, Takahashi H, et al. Round window application of an active middle ear implant: a comparison with hearing aid usage in Japan. Otol Neurotol, 2017; 38: e145-51.

28. Suzuki J, Kodera K, Yanagihara N. Middle ear implant for humans. Acta Otolaryngol, 1985 Apr; 99: 313-7.

29. Luetje CM, Brackman D, Balkany TJ, et al. Phase III clinical trial results with the Vibrant Soundbridge implantable middle ear hearing device: a prospective controlled multicenter study. Otolaryngol Head Neck Surg, 2002 Feb; 126: 97-107.

30. Goode RL, Ball G, Nishihara S, Nakamura K. Laser Doppler vibrometer (LDV): a new clinical tool for the otologist. Am J Otol, 1996 Nov; 17: 813-22.

31. Labassi S, Beliaeff M, Péan V, Van de Heyning P. The Vibrant Soundbridge ${ }^{\circledast}$ middle ear implant: a historical overview. Cochlear Implants Int, 2017; 18: 314-23.

32. Rahne T. [Physical audiological principles of implantable hearing systems]. HNO, 2019 Nov 8.

33. Arthur D. The Vibrant ${ }^{\oplus}$ Soundbridge ${ }^{\mathrm{TM}}$. Trends Amplif, 2002 Jun; 6: 67-72.

34. Fisch U, Cremers CW, Lenarz T, et al. Clinical experience with the Vibrant Soundbridge implant device. Otol Neurotol, 2001 Nov; 22: 962-72.

35. Mühlmeier G, Aigner E, Brumma I, Schlegel A, Tisch M. Benefit from an audio processor upgrade in experienced users of an active middle ear implant: speech understanding in noise and subjective assessment. J Hear Sci, 2020 Apr 9; 8: 27-34.

36. Zimmermann D, Busch S, Lenarz T, Maier H. Audiological results with the Samba audio processor in comparison to the Amade for the Vibrant Soundbridge. Audiol Neurootol, 2020; 25: 164-72.

37. Rameh C, Meller R, Lavieille J-P, Deveze A, Magnan J. Long-term patient satisfaction with different middle ear hearing implants in sensorineural hearing loss. Otol Neurotol, 2010 Aug; 31: 883-92.

38. Mlynski R, Nguyen TD, Plontke SK, Kösling S. Presentation of floating mass transducer and Vibroplasty couplers on CT and cone beam CT. Eur Arch Otorhinolaryngol, 2014 Apr; 271: 665-72. 